Chronologia (2021) vol. 3 no. 2 hal. 79-88

http://dx.doi.org/10.22236/jhe.v3i2.7800

E-ISSN: 2686-0171

\title{
Pengembangan Pembelajaran Sejarah Berbasis Microsoft Teams Untuk Membentuk Kecakapan Abad 21
}

\section{Development of History Learning Based on Microsoft Team To Shape $21^{\text {st }}$ Century Skills}

\author{
Asyif Awaludin Romadhoni ${ }^{1 \bowtie}$, Supardi ${ }^{2}$, Aman $^{3}$ \\ ${ }^{1 \bowtie 23}$ Magister Pendidikan Sejarah, Universitas Negeri Yogyakarta \\ E-mail: asyifawaludin.2020@student.uny.ac.id ${ }^{1 凶}$, pardi@uny.ac.id ${ }^{2}$, aman@uny.ac.id ${ }^{3}$
}

Diterima: 1 November 2021 | Direvisi: 29 November 2021 | Diterbitkan: 29 November 2021

ARTICLE INFO

Keywords:

History Learning Model,

Microsoft Teams,

Student.

\section{Kata Kunci:}

Model Pembelajaran Sejarah, Microsoft Teams,

Peserta Didik.
ABSTRACT

The Covid-19 pandemic has changed all aspects of human life. One of them is education. The government has launched a Learning From Home (BDR) policy to tackle the spread of COVID-19. This has an impact on the learning process and inculcating character values among the younger generation. History learning certainly plays an important role in shaping the character of the younger generation and becomes one of the solutions to moral decadence during the pandemic. Therefore, history learning needs to be arranged creatively by innovating learning technology, one of which is Microsoft Teams. This article aims to describe a Microsoft Teams-based history learning model by incorporating learning technologies such as broadcast. This article is written with descriptive writing method. The theories used to analyze and develop this learning model include the concepts of understanding, feeling, acting, and the example of Ki Hadjar Dewantara; the Smart School and Good School concepts developed by Matthew Davidson, Thomas Lickona, and Vladimir Khmelkov; and the concept of Teaching Controversial Issues based on Thomas Lickona's research. The history learning model based on Microsoft Teams consists of several stages, namely Preparation of Learning Implementation Plans (RPP); Material Ray Making; Asynchronous Learning by sharing podcasts of material into Teams Classes; Synchronous Learning Discussing Rays; Synchronous Learning that Discusses the Perspective of Characters, Historical Actors, or Experts and Discusses; and Control of Character Guidance with Homeroom and Counseling Teachers. This model can be applied in history learning in an effort to inculcate character values and competencies in the 21st century by inviting students to continue to plan and realize good plans for the better.

Pandemi Covid-19 telah mengubah seluruh aspek tatanan kehidupan manusia. Salah satunya adalah pendidikan. Pemerintah mencetuskan kebijakan Belajar Dari Rumah (BDR) untuk menanggulangi penyebaran covid19. Hal ini berdampak pada proses pembelajaran dan penanaman nilai karakter di kalangan generasi muda. Pembelajaran sejarah tentu berperan penting dalam membentuk karakter generasi muda dan menjadi salah satu solusi dekadensi moral di masa pandemi. Oleh karena itu, pembelajaran sejarah perlu disusun secara kreatif dengan menginovasikan teknologi pembelajaran salah satunya ialah Microsoft Teams. Artikel ini bertujuan untuk menggambarkan model pembelajaran sejarah berbasis Microsoft Teams dengan menggabungkan teknologi pembelajaran seperti siniar. Artikel ini ditulis dengan metode penulisan deskriptif. Teori yang digunakan untuk 
menganalisis dan mengembangkan model pembelajaran ini diantaranya adalah adalah konsep ngerti, ngrasa, nglakoni, dan keteladanan Ki Hadjar Dewantara; konsep Sekolah Pintar dan Sekolah Baik yang dikembangkan oleh Matthew Davidson, Thomas Lickona, dan Vladimir Khmelkov; serta konsep Pengajaran Isu Kontroversial berdasarkan penelitian Thomas Lickona. Model pembelajaran sejarah berbasis Microsoft Teams terdiri atas beberapa tahap yaitu Penyusunan Rencana Pelaksanaan Pembelajaran (RPP); Pembuatan Siniar Materi; Pembelajaran Asinkron dengan membagikan podcast materi ke dalam Kelas Teams; Pembelajaran Sinkron yang Membahas Siniar; Pembelajaran Sinkron yang Membahas Sudut Pandang dari Tokoh, Pelaku Sejarah, atau Pakar dan Berdiskusi; serta Kontrol Pembimbingan Karakter bersama Wali Kelas dan Guru BK. Model ini dapat diterapkan dalam pembelajaran sejarah dalam upaya penanaman nilai karakter dan kompetensi abad 21 dengan mengajak peserta didik untuk tetap merencanakan dan merealisasikan rencana kebaikan agar semakin lebih baik lagi.

\section{PENDAHULUAN}

Sejak ditemukan di Wuhan, Cina pada Desember 2019, virus Covid-19 terus menyebar hingga melahirkan pandemi yang melanda hampir seluruh dunia. Akibat hal ini Indonesia juga turut terkena imbasnya dalam berbagai sektor, termasuk sektor pendidikan. Untuk mengatasi ancaman tersebut, maka Menteri Pendidikan dan Kebudayaan Nadiem Anwar Makarim menerbitkan Surat Edaran Nomor 4 Tahun 2020 tentang Pelaksanaan Pendidikan dalam Masa Darurat Coronavirus Disease (Covid-19). Kegiatan pendidikan di sekolah yang biasanya dilakukan secara tatap muka dialihkan menjadi pembelajaran via daring dengan menggunakan media tertentu seperti Google Classroom, Microsoft Teams, Edmodo, Whatsapp Group, Zoom Meeting, Webex serta beberapa platform lain untuk mendukung pembelajaran dari rumah.

Sebagian sekolah pun telah menggunakan sistem manajemen pembelajaran yang dikenal sebagai Learning Management System (LMS). Pembelajaran seperti ini dikenal sebagai pembelajaran dalam jarungan atau daring. Hal ini semata-mata ditujukan untuk mencegah penularan Covid-19.
Tantangan pembelajaran daring saat ini cukup berat bagi guru dan peserta didik. Guru mengalami kesulitan berkomunikasi dengan orang tua selama pandemi karena tidak bisa menyampaikan secara langsung kendala yang dialami selama pembelajaran sehingga kegiatan pembelajaran akan berdampak pada peserta didik yang rentan dengan stress bahkan akan berdampak pada tingginya angka putus sekolah. Peserta didik pun mengalami dampak psikososial yang luar biasa dimana tekanan pembelajaran dan tekanan dari rumah cukup menghambat aktivitasnya selama pembelajaran daring.

Berbagai tekanan yang dihadapi oleh peserta didik dikhawatirkan akan berdampak pada pembentukan karakter yang kurang maksimal. Hal tersebut justru dapat menjadi lebih parah jika guru tidak mengembangkan pembelajaran yang kreatif dan menyenangkan selama pandemi. Handarini \& Wulandari (2020) menyebutkan masih banyak dijumpai guru yang tidak kreatif dalam mengemas pembelajaran selama pandemi.

Melihat perkembangan tersebut, hakikat pembelajaran seharusnya bisa memberikan keleluasaan kepada peserta didik untuk belajar tentang apa yang dialaminya. Pembelajaran 
dapat diartikan sebagai proses interaksi antara guru dengan peserta didik dengan mendekatkan sumber belajar dan menjadikan peserta didik untuk mau belajar (Sardiman, 2004). Melalui proses pembelajaran inilah, peserta didik diharapkan dapat memiliki kepribadian kebangsaan yang cakap dan terampil menghadapi perkembangan zaman (Rahayu, 2018). Untuk itulah pendidikan karakter diperlukan dalam menghadapi situasi apapun, termasuk pandemi Covid-19 sekarang.

Proses pembelajaran dalam masa pandemi merupakan hal yang mau tidak mau harus dilaksanakan agar Indonesia tidak kehilangan generasinya untuk membangun kemajuan bangsa. Pembelajaran jarak jauh semakin menegaskan bahwa kedudukan guru bukanlah seseorang yang tahu akan segala hal. Pendidikan di masa pandemi diharapkan mampu untuk meningkatkan kemampuan berpikir kritis, komunikasi, kreativitas, serta kolaborasi (Savitri, 2019). Kemampuan tersebut merupakan tuntutan Revolusi Industri 4.0 dimana kondisi krisis saat ini tidak menutup kemungkinan akan memberikan hal yang tidak pasti kepada masyarakat.

Untuk menyikapi hal tersebut, pembelajaran sejarah sangat diperlukan dalam rangka revitalisasi karakter peserta didik. Pembelajaran sejarah diperlukan dalam rangka untuk memberikan gambaran tentang peristiwa yang terjadi di masa lalu agar menjadi pembelajaran di masa kini dan masa yang akan datang. Meskipun dalam situasi pandemi, pembelajaran sejarah tetap menjadi prioritas untuk membentuk karakter generasi muda di tengah semakin berkembangnya pengaruh negatif globalisasi. Melihat hal tersebut, pembelajaran sejarah justru dapat dijadikan sebagai wahana hiburan dan memberikan inspirasi peserta didik agar mau belajar dan melakukan hal yang baik. Guru pun dapat mengemasnya dengan menerapkan berbagai media yang digandrungi peserta didik saat ini seperti mengintegrasikannya dengan sosial media Tiktok, Instagram, serta siniar yang dikombinasi dengan LMS (Learning Management System).

Media tersebut dapat dikombinasikan dengan salah satu LMS yaitu Microsoft Teams. LMS tersebut dikembangkan oleh Microsoft Corporation yang mendukung proses pembelajaran secara asinkron dan sinkron (Microsoft Indonesia, 2019). Microsoft Teams memiliki berbagai fitur yang bisa digunakan dalam satu aplikasi, mulai dari meeting, pengumpulan tugas, pembuatan kuis, membagikan materi dari YouTube, serta berbagai fitur lainnya yang sangat unggul dibandingkan dengan platform lainnya. Dengan kelebihan inilah, penulis tertarik untuk mengembangkan sebuah model pembelajaran sejarah dengan mengintegrasikan siniar dan Microsoft Teams untuk membentuk kecakapan dan karakter Abad 21 bagi peserta didik. Lebih dari itu penelitian ini juga memiliki kebaharuan apabila dibandingkan dengan penelitian lainnya. Diantaranya yaitu:

Pertama, penelitian milik Nurlaily Faziatun pada tahun 2021 dengan judul "Implementasi Microsoft Teams For Education dalam Pembelajaran Pendidikan Agama Islam dan Budi Pekerti di SMP Negeri 1 Purwokerto". Penelitian ini memiliki kesamaan karena mengkaji tentang microsoft teams, akan tetapi 
Romadhoni, Supardi \& Aman, 2021, Pengembangan Pembelajaran ...

jika ditelisik lebih dalam maka terdapat perbedaan besar antara riset miliki peneliti dengan artikel Faziatun. Riset milik peneliti lebih menekankan pada pengembangan microsof teams sebagai sarana pembelajaran sejarah. Sedangkan milik Faziatun berpusat pada pemanfaatan microsof teams dalam pembelajaran agama dan fitur-fitur yang dapat digunakan, sehingga jauh lebih kompleks.

Kedua, penelitian dengan judul "Implementasi Keterampilan Abad 21 dalam Pembelajaran Sejarah Kebudayaan Islam di Madrasah Tsanawiyah Negeri 1 Kota Malang" yang dilakukan oleh Mela Meriana. Riset ini memiliki kesamaan karena sama-sama memfokuskan pada pembelajaran sejarah dan penggunaan keterampilan di abad 21. Walaupun demikian, riset Meriana keterampilan abad 21 yang digunakan begitu luas dan tidak memasukan unsur microsoft teams. Hal inilah yang menjadi pembeda dasar dengan artikel milik peneliti.

Perbedaan lainnya yang membedakan riset milik peneliti dengan kedua artikel di atas yakni terkait model yang diterapkan dalam meneliti. Model yang dikembangkan peneliti nantinya akan dapat mengajak peserta didik merefleksikan nilai-nilai dari peristiwa sejarah yang telah dipelajari ke dalam perilaku seharihari dengan berkolaborasi bersama wali kelas dan guru BK peserta didik. Konsep ini akan membantu proses penanaman nilai karakter dengan mudah dan terintegrasi satu sama lain.

\section{METODE}

Kajian ini menggunakan metode penulisan deskriptif dengan didasarkan pada beberapa teori pendidikan karakter. Teori-teori tersebut diantaranya adalah konsep ngerti, ngrasa, nglakoni, dan keteladanan Ki Hadjar Dewantara, (2011) konsep Sekolah Pintar dan Sekolah Baik yang dikembangkan oleh Davidson, Lickona, \& Khmelkov, (2014) dalam bukunya Handbook Pendidikan Moral dan Karakter.

Tiga teori tersebut menjadi dasar pengembangan pembelajaran yang mengintegrasikan media pembelajaran berbasis teknologi informasi dan Microsoft Teams. Pengintegrasian tersebut diharapkan dapat memberikan pengalaman belajar yang menarik dan dikenang oleh peserta didik sehingga selain materi pengetahuan dapat dipahami dengan baik juga penanaman nilai karakter akan dipahami serta diamalkan dalam kehidupan sehari-hari.

Model ini akan berkolaborasi dengan beberapa pihak seperti tokoh atau pakar sejarah yang memahami materi tertentu, wali kelas dan guru BK sebagai pihak yang ikut serta memberikan pengarahan dan bimbingan, serta guru sejarah sebagai pelaku pelaksana program tersebut. Dengan demikian sumber daya yang digunakan dalam hal ini adalah para sejarawan dan guru sekolah yang bersangkutan. Untuk selanjutnya, karena penggunaan media berbasis microsof teams ini cukup kompleks maka yang menjadi sasarannya adalah anak SMA. Penerapan model ini diharapkan dapat menanamkan berbagai kompetensi kecakapan abad 21 seperti kreativitas, komunikasi, kolaborasi, serta kemampuan berpikir kritis bagi peserta didik. Penanaman kompetensi tersebut akan berimplikasi pada karakter peserta didik yang bisa menjadi pribadi yang cakap dan terampil dalam menghadapi tantangan zaman. 
HASIL DAN PEMBAHASAN

\section{Tahapan Pembelajaran Sejarah Meng- gunakan Microsoft Teams}

Tahapan-tahapan pembelajaran sejarah dilakukan dengan mengintegrasikan pembelajaran asinkron dengan pembelajaran sinkron. Media yang digunakan dalam model ini adalah siniar dan Microsoft Teams. Model pembelajaran ini nantinya akan dilakukan selama tiga kali pertemuan dengan tagihan peserta didik yaitu membuat catatan refleksi diri terhadap materi yang telah dipelajari dan akan dilaksanakan dalam kehidupan sehari-hari. Jika terdapat sikap perilaku yang tidak tercermin sesuai refleksi sebelumnya, maka guru sejarah akan bekerjasama dengan wali kelas dan guru BK untuk mengarahkan dan membimbing peserta didik agar menjadi lebih baik lagi. Tahapan tersebut diantaranya adalah sebagai berikut.

\section{a. Penyusunan Rencana Pelaksanaan Pembelajaran (RPP)}

Pada tahap ini, guru akan menyusun RPP sesuai dengan materi yang akan disajikan kepada peserta didik. Di dalam perangkat tersebut terdapat media yang akan digunakan serta langkah-langkah pembelajaran yang akan dilaksanakan sesuai dengan karakteristik materi yang disajikan. Guru akan merumuskan nilai-nilai karakter yang akan ditanamkan kepada peserta didik selama pembelajaran sesuai dengan materi yang dipilih. Selain itu topik yang dipilih dengan tujuan pembelajaran serta media yang digunakan perlu disesuaikan agar mendapatkan hasil yang maksimal. Karena antara metode dan media sangat menentukan keberhasila sebuah materi yang disampaikan dalam kajian sejarah. Lebih dari itu tujuan pembelajaran adalah bagian vital yang harus terpenuhi demi mengoptimalkan fungsi pembelajaran sejarah di sekolah. Oleh sebab koordinasi dan keseimbangan antara tiga unsur ini sangat penting.

\section{b. Pembuatan Podcast atau Siniar Materi}

Proses pembuatan podcast atau siniar dapat dilakukan dengan berbagai aplikasi perekam suara atau aplikasi penyiar radio. Dalam hal ini penulis memilih untuk menggunakan aplikasi Anchor. Menurut hemat penulis, aplikasi tersebut lebih mudah untuk melakukan perekaman hingga melakukan penyuntingan sesuai dengan kreativitas guru. Dalam proses pembuatan siniar pula, guru harus mengumpulkan bahan materi untuk disajikan sebagai rekaman siniar. Namun perlu dipertegas kembali, materi yang akan dijadikan konten dalam hal ini perlu dianalisis secara mendalam kembali. Karena tidak semua materi sejarah tepat untuk dijadikan sebuah podcast yang hanya bermodalkan suara tanpa rekaman. Dikarenakan beberapa materi sejarah perlu ditampilkan gambar juga, demi memaksimalkan proses pembelajaran. Beberapa materi yang dirasa relevan untuk digunakan sebagai podcast antara lain, pengertian dan ruang lingkup ilmu sejarah, manusia purba di Indonesia, peradaban hindu-budha Nusantara dan materi lainnya yang relevan. 
Romadhoni, Supardi \& Aman, 2021, Pengembangan Pembelajaran ...

c. Pertemuan Pertama: Pembelajaran Asinkron dengan membagikan siniar materi ke dalam Kelas Microsoft Teams yang telah dibuat

Pada tahap ini, siniar yang telah dibuat sebelumnya kemudian dibagikan ke dalam bentuk tautan khusus yang dapat diakses dengan mudah. Tautan tersebut kemudian dibagikan ke dalam Kelas Maya di Microsoft Teams yang telah dibuat.

Setelah membagikan tautan siniar, guru kemudian mencanangkan pembelajaran sejarah dilakukan secara asinkron. Peserta didik diminta untuk mendengarkan podcast yang telah dibagikan ke kelas Teams. Guru kemudian diberikan ketentuan pembelajaran agar peserta didik memahami langkah pembelajaran yang akan dilakukan. Hal ini termasuk ke dalam penanaman nilai disiplin dan berpikir kritis karena peserta didik diminta untuk menaati ketentuan yang telah diberikan oleh guru.

Tujuan pembelajaran asinkron ini adalah agar peserta didik memahami dan bisa mengeksplorasi materi lebih jauh setelah mendengarkan materi yang disajikan melalui siniar. Meskipun terkesan satu arah, peserta didik akan merasa lebih mudah mengikuti pembelajaran karena masih banyak dijumpai peserta didik yang menginginkan guru sebagai fasilitator dalam menguatkan materi.

Apabila selama pandemi saat ini peserta didik diminta untuk mencari materi sendiri tanpa ada dasar pemahaman yang jelas, maka akan dikhawatirkan terjadi miskonsepsi pemahaman antara peserta didik dengan guru. Penyampaian materi yang disajikan guru melalui siniar pula disesuaikan dengan karakteristik materinya.

\section{d. Pertemuan Kedua: Pembelajaran Sinkron dengan Membahas Tanggapan dan Sudut Pandang setelah mendengarkan siniar}

Pada pertemuan ini, guru mengagendakan pembelajaran dilakukan secara sinkron dengan menggunakan fitur meeting kelas yang ada di Teams. Tujuannya adalah untuk mengembangkan kemampuan berpikir kritis peserta didik serta menanamkan iklim kolaborasi, kreativitas dalam berpendapat, serta menghargai perbedaan pendapat yang ada.

Pertemuan tatap maya tersebut akan membahas beberapa hal utamanya adalah pendapat peserta didik setelah mendengarkan siniar yang disajikan sebelunya sehingga beberapa dapat memahami dan mengeksplorasi materi. Di sini, peserta didik harus menggunakan fitur raise hand selama berdiskusi karena jika tidak menggunakan fitur tersebut akan terjadi kekacauan selama diskusi. Guru di sini bertindak sebagai moderator yang selalu memancing bahan berdiskusi peserta didik sehingga keterlibatannya akan berusaha menggali seluruh kemampuan peserta didik.

Peserta didik pula dalam hal ini akan diasah kemampuan berpikir kritis dan kreativitasnya dalam menyampaikan argumentasi terhadap materi yang telah dipelajari. Hal ini akan mengajarkan sikap percaya diri dan karakter menghargai perbedaan pendapat. Sesi diskusi tersebut dapat dilakukan dengan mendukung argumentasi teman atau membantah 
argumentasi teman yang lain. Proses pembelajaran ini nantinya akan direfleksikan bersama dengan guru tentang kaitannya dalam kehidupan sehari-hari.

\section{e. Pertemuan Ketiga: Pembelajaran Sinkron} dengan Membahas Sudut Pandang dari Tokoh, Pelaku Sejarah, atau Pakar setelah Mendengarkan siniar dan Berdiskusi

Pada tahap ini, guru mengagendakan pembelajaran berlangsung secara sinkron untuk membahas sudut pandang lain dari tokoh, pelaku sejarah, atau pakar setelah peserta didik melakukan diskusi pada pertemuan sebelumnya. Hal ini akan memberikan nuansa pembelajaran baru karena mereka dapat mengetahui bahkan membuktikan pendapatnya secara langsung dengan narasumber pembelajaran. Dalam kegiatan ini, guru tentu berkolaborasi dengan narasumber sebagai teman belajar peserta didik. Tujuannya agar peserta didik memiliki pengalaman dan kesan belajar yang baik serta mendapatkan wawasan yang baru pula di luar hafalan atau ilmu yang telah dipelajari dari guru atau dari temannya.

Narasumber di sini pula berperan penting untuk memberikan wawasan secara umum kepada peserta didik agar nantinya peserta didik mampu menerapkan nilai-nilai yang didapatkan dari materi sejarah yang dipelajari ke dalam kehidupan sehari-hari. Konsep inilah yang akan membentuk pengetahuan dan sikap peserta didik yang nantinya dapat direfleksikan dalam kehidupan sehari-hari. Tagihan pertemuan ini nantinya peserta didik akan merefleksikan proses pembelajaran ke dalam rencana nyata yang akan dilakukan dalam kehidupannya sehari-hari berdasarkan materi sejarah dan proses yang dialaminya. Rencana tersebut kemudian dikumpulkan dan menjadi alat kontrol guru untuk membimbing peserta didik.

\section{f. Kontrol Pembimbingan Karakter bersama Wali Kelas dan Guru BK}

Kontrol pembimbingan karakter akan dilakukan ketika peserta didik dalam proses pembelajaran daring melakukan sikap yang tidak sesuai dengan refleksi rencana nyata yang akan dilakukan dalam kehidupan sehari-hari untuk kehidupan yang lebih baik lagi. Mekanisme yang dilakukan nantinya adalah guru sejarah akan menyampaikan langsung kepada wali kelas yang diampunya mengenai masalah pembelajaran yang dilanggar oleh peserta didik tertentu. Dari situlah wali kelas akan melakukan pembimbingan sesuai dengan refleksi peserta didik yang bersangkutan dengan bantuan guru BK terkait. Kegiatan ini sematamata akan memberikan pendampingan khusus agar peserta didik dapat memiliki karakter yang baik sesuai dengan yang dituliskan dan direncanakan oleh peserta didik tersebut.

Berdasarkan uraian di atas, model ini tentu dapat diterapkan dalam pembelajaran sejarah dalam upaya penanaman nilai karakter dan kompetensi abad 21. Hal ini dilakukan dengan mengintegrasikan teknologi seperti siniar dan Microsoft Teams selama pandemi Covid-19 saat ini. Pendampingan yang dilakukan pula akan berdampak baik bagi peserta didik karena 
Romadhoni, Supardi \& Aman, 2021, Pengembangan Pembelajaran ...

proses pembelajaran pada hakikatnya akan membentuk karakter perserta didik agar lebih baik lagi. Di samping itu, guru dapat memahami karakteristik peserta didik dari proses membaca refleksi yang dilakukan sehingga setiap proses pembelajaran akan memperhatikan kebutuhan dan karakteristik materi di samping pemahaman peserta didik. Oleh karena itulah, model pembelajaran sejarah dengan mengintegrasikan akan mengajak peserta didik untuk tetap merencanakan dan merealisasikan rencana kebaikan agar semakin lebih baik lagi.

\section{Peluang dan Hambatan Penggunaan Media Berbasis Microsoft Teams dalam Pembelajaran Sejarah di Abad 21}

Pandemi Covid-19 yang melanda hampir seluruh dunia termasuk Indonesia memberikan tantangan yang luar biasa dalam berbagai bidang. Pendidikan adalah salah satu yang terkena efeknya dan mau tidak mau harus mampu beradaptasi dengan keadaan tersebut, salah satunya dengan menerapkan pembelajaran secara daring. Dengan memanfaatkan kecanggihan teknologi yang ada, pihak sekolah mencoba menyusun sedemikian rupa metode yang dapat digunakan dalam proses pembelajaran jarak jauh ini (Putria, Maula, \& Uswatun, 2020). Salah satu langkah yang ditempuh yaitu dengan menggunakan media Microsoft Teams untuk pembelajaran.

Microsoft Teams merupakan sebuah program software yang di dalamnya terkandung berbagai macam unsur. Mulai dari penyimpanan file, panggilan telpon, catatan, kalender hingga obrolan. Oleh sebab itu pengguna dapat menggunakan software ini dengan begitu leluasa untuk menjalin kerjasama. Apalagi keamanan yang diusung oleh software ini begitu kuat setingkat sebuah perusahaan sehingga data yang tersimpan terjamin keamanannya (Fauziatun, 2021)

Dengan segala fasilitas yang tersedia dalam Microsoft Teams, tidak dengan mudah menjadikan software ini populer di kalangan siswa maupun guru, dikarenakan memiliki kekurangan atau hambatan ketika digunakan. Beberapa hambatan tersebut antara lain: pertama, harga lisesi resminya yang begitu mahal jika dibandingkan dengan beberapa media pembelajaran daring lainnya seperti google meet, google classroom, zoom atau bahkan WhatsApp. Belum lagi ditambah biaya pembuatan domain. Dimasa pandemi yang membuat hampir setiap sektor mengalami keterpurukan dan terpaksa melakukan PHK (Pemutusan Hak Kerja), sudah tentu harga menjadi pertimbangan yang penting. Kedua, Pengoperasian yang begitu sulit. Bahkan untuk taraf siswa SMA sendiri hampir 30\% yang masih mengalami kesulitan dalam menjalankan software ini di awal penggunaannya. Walaupun setelah beberapa kali pertemuan dapat digunakan dengan baik. Ketiga, terlalu rumit untuk digunakan oleh para guru terutama guru sejarah. Karena harus menyediakan berbagai macam hal untuk persiapan, belum lagi ditambah dengan proses pembuatan materi yang akan diajarkan atau dikirimkan ke siswa. Selain beberapa hambatan yang berkaitan langsung dengan Microsoft Teams. Hambatan lainnya yang dialami oleh guru dan siswa dalam penggunaan software ini yaitu masalah jaringan dan penggunaan kuota. Karena tidak dapat dipungkiri apabila sistem pembelajaran jarak 
jauh ini erat kaitannya dengan penggunaan internet (Wirza \& Ofionto, 2021).

Dengan berbagai macam kekurangan tersebut penggunaan Microsoft Teams memiliki beberapa kelebihan yang tidak dapat dipandang sebelah mata, selain dengan fitur yang disediakannya. Beberapa kelebihan tersebut antara lain: pertama, pembelajaran tidak monoton. Pembelajaran sejarah sering dianggap membosankan karena metode yang digunakan hanya ceramah saja, akan tetapi dengan adanya Microsoft Teams akan memberikan kesempatan kepada guru untuk memilih opsi teknik apa yang akan digunakan dalam mengajar di kelas, misalnya pada pertemuan minggu pertama menggunakan podcast, dan untuk selanjutnya diskusi secara vistual terkait materi sejarah. Secara otomatis dengan beragam metode yang digunakan tersebut, akan membuat siswa tidak jenuh dalam belajar sejarah di kelas. Kedua, siswa dapat terhubung dengan lebih baik, sehingga pekerjaan kelompok dapat dikerjakan secara maksimal dan terstruktur. Selain itu juga dengan keterhubungan ini, para guru dapat memantau setiap peserta didik dengan jauh lebih baik. Dengan demikian guru dapat mengetahui bagaimana peserta didik membagi tugas antar temen sekelompoknya.

Ketiga, peserta didik lebih disiplin lagi, karena waktu yang telah ditetapkan tidak dapat dirubah. Namun apabila terdapat peserta didik yang berhalangan masuk, maka mereka masih dapat menyimak melalui hasil rekaman pembelajaran yang telah berlangsung. Akibatnya kemungkinan peserta didik untuk tertinggal dalam suatu pembelajaran menjadi minim. Apalagi pembelajaran sejarah yang hampir setiap materinya memiliki korelasi yang tidak dapat dipisahkan. Bahkan beberapa materi dapat menjadi vital apabila peserta didik hanya mendengarnya setengah saja. Misalnya materi G30S/PKI yang begitu krusial apabila peserta didik hanya mendengar satu saja teori pelaku dalam peristiwa ini karena dapat mempengaruhi cara pandang peserta didik dalam menyikapi suatu fenomena. Padahal salah satu tujuan utama pembelajaran sejarah sendiri yaitu menanamkan sifat bijak dalam diri peserta didik.

Mengacu pada berbagai aspek tersebut maka dapat diketahui apabila penggunaan Microsoft Teams dalam pembelajaran sejarah di sekolah memiliki berbagai macam hambatan dan kekurangan. Walaupun demikian tidak dapat dinafikan pula apabila di satu sisi penggunaan media ini memberikan nuansa yang berbeda dalam pembelajaran sejarah di sekolah apabila dibandingkan dengan penggunaan software daring lainnya.

\section{KESIMPULAN}

Berdasarkan uraian pembahasan di atas maka dapat ditarik sebuah simpulan yaitu model pembelajaran sejarah berbasis Microsoft Teams terdiri atas beberapa tahap yaitu Penyusunan Rencana Pelaksanaan Pembelajaran (RPP); Pembuatan Siniar Materi; Pertemuan Pertama: Pembelajaran Asinkron dengan membagikan podcast materi ke dalam Kelas Microsoft Teams yang telah dibuat; Pertemuan Kedua: Pembelajaran Sinkron dengan Membahas Tanggapan dan Sudut Pandang setelah mendengarkan podcast, Pertemuan Ketiga: 
Pembelajaran Sinkron dengan Membahas Sudut Pandang dari Tokoh, Pelaku Sejarah, atau Pakar setelah Mendengarkan Siniar dan Berdiskusi; serta Kontrol Pembimbingan Karakter bersama Wali Kelas dan Guru BK. Model ini tentu dapat diterapkan dalam pembelajaran sejarah dalam upaya penanaman nilai karakter dan kompetensi abad 21 dengan mengajak peserta didik untuk tetap merencanakan dan merealisasikan rencana kebaikan agar semakin lebih baik lagi.

\section{DAFTAR PUSTAKA}

Davidson, M., Lickona, T., \& Khmelkov, V. (2014). Handbook Pendidikan Moral dan Karakter. Bandung: Nusa Media.

Dewantara, K. H. (2011). Bagian Pertama: Pendidikan. Yogyakarta: Yayasan Persatuan Tamansiswa.

Fauziatun, N. (2021). Implementasi Microsoft Teams For Education dalam Pembelajaran Pendidikan Agama Islam dan Budi Pekerti di SMP Negeri 1 Purwokerto (Institut Agama Islam Negeri Purwokerto). Institut Agama Islam Negeri Purwokerto. Retrieved from http://repository.iainpurwokerto.ac.id/10361/1/ NURLAILY FAUZIATUN IMPLEMENTASI MICROSOFT TEAMS FOR EDUCATION DALAM PEMBELAJARAN PENDIDIKAN AGAMA ISLAM DAN BUDI PEKERTI DI SMP NEGERI 1 PURWOKERTO.pdf

Handarini, O. I., \& Wulandari, S. S. (2020). Pembelajaran Daring Sebagai Upaya Study From Home (SFH). Jurnal Pendidikan Administrasi Perkantoran (JPAP), 8(3), 465503.

Indonesia, M. (2019). Kelas Digital dengan Microsoft Teams. Jakarta: Microsoft Indonesia Inc.

Putria, H., Maula, L. H., \& Uswatun, D. A. (2020). Analisis Proses Pembelajaran dalam Jaringan (DARING) Masa Pandemi Covid- 19 Pada Guru Sekolah Dasar. Jurnal Basicedu, 4(4), 861-870. https://doi.org/10.31004/basicedu.v4i4.460

Rahayu, P. (2018). Belajar Sejarah dari Lingkungan dan Permainan. Surabaya: Media Guru.
Sardiman. (2004). Interaksi dan Motivasi Belajar Mengajar. Jakarta: Raja Grafindo Persada.

Savitri, A. (2019). Revolusi Industri 4.0: Mengubah Tantangan menjadi Peluang di Era Disrupsi 4.0. Yogyakarta: Genesis.

Wirza, M. A., \& Ofionto. (2021). Penggunaan Microsoft Teams dalam Pembelajaran Daring pada Mata Pelajaran Sejarah di SMA Negeri 1 Bukittinggi. Journal Kronologi, 3(1), 106118. 